\title{
COMPARATIVE ANALYSIS OF THE TEMPORARY SERVICE CONTRACT IN THE LEGAL SYSTEMS OD THE REPUBLIC OF SERBIA, NORTHERN MACEDONIA AND EUROPEAN COUNTRIES
}

\author{
PhD Sanja Maksimović, Assistant Professor \\ Law Faculty for Commerce and Judiciary \\ University Business Academy in Novi Sad \\ sanja.m03@gmail.com \\ PhD Marko Stanković, Assistant Professor \\ Law Faculty for Commerce and Judiciary \\ University Business Academy in Novi Sad \\ marko.stankovic@pravni-fakultet.info
}

\begin{abstract}
:
The need for research and analysis of temporary service contracts is self-evident, given the fact that this contract in modern law has significantly expanded its scope of application, especially to various intellectual, cultural, scientific and other agency work, with several new rules in the field and rights and obligations of the contracting parties. Nevertheless, the basic ideas, the legal cornerstone of the temporary service contract, such as the concept, consensual character and basic rights and obligations still remain the same in modern law, but with the addition of legal solutions on other components in accordance with the needs of modern life and labor market, which will be explained further in the paper.
\end{abstract}

Keywords: Service Contract, Comparison, Legislation of European Countries

\section{Introduction}

Temporary service contracts, by which we consider contracts which by their essential properties and their genesis represent an agreement whereby a contractor supplies time, effort, and/or expertise instead of a good (tangible product) in modern law, through which get their uniqueness and autonomy, so they represent a nominated contract, thus separating itself from its genus. It can be concluded that the legal evolution of the temporary service contract shows that this contract has survived all socio-economic systems since its inception, and that from its genu new similar nominated contracts emerged that retained all its features, which certainly indicates its importance in law, ensuring that it remains a focal point of legal theory. A service contract, as defined by Serbian legal system, is a type of contract by which one person (employee, the contractor - conductor) is obligated to perform a certain job for another person (client) and achieve a certain result, and the client is obligated to pay a certain amount (fee) for contractors services. From this definition, 
it can be concluded that a temporary service contract is a contract by which the contractor is obliged to perform a certain job, and the client is obliged to pay adequate compensation for the performed work. It follows from the abovementioned definition that the subject of the client's obligation is the payment of compensation. The basic features of the temporary service contract can also be derived from its legal definition. It is a nominate contract, bilaterally binding, onerous, informal (consensual), and commutative. It can also have the property of a contract intuitu personae when the ordering party concludes it with regard to the special properties (professional, scientific, artistic) of the contractor, in which case he cannot transfer his obligation to a third party (manufacturer). The immanent property of this contract is precisely the fact that this contract covers a wide variety of possible services that can be provided by the contractor because it includes jobs based on tangible products such as e.g. production, repair, transportation, but also works of artistic, scientific or literal vocation. The dissolution of Yugoslavia ended with the formation of six separate states, and each of them had to create a new legal system, in addition to the other problems it faced. After a transitional period in which the law of the former republic was applied, these states began their own legislative activity in accordance with the current process of developing free-market conditions, private property, and credit relations. When it comes to the field of civil law, it is interesting that none of the newly formed states fully regulated this matter with the Civil Code, except for the Republic of Serbia, which is working on an all-encompassing civil code, instead all states opted for partial regulation of certain branches of civil law - probably in order to adapt to the new capitalist relations and for them to be established and stabilized. The experiences of the former Yugoslav republics ${ }^{1}$ are very similar. The Republic of Slovenia, Croatia, Montenegro, Serbia, Macedonia, and the entities of Bosnia and Herzegovina decided to retain a number of solutions, as well as the concept of the Federal Law on Obligations ${ }^{2}$, all former states made certain changes and adopted this law as their new national law. The changes that the former Yugoslav republics introduced in their codes referred to the number and types of individual contracts. Introducing and passing of laws governing obligations or civil law is one of the most important legislative endeavors for any state. Such laws take a long time to prepare and are applicable for a longer period of time because the obligatory relations change very slowly. Therefore, it can be understood why in some European countries, such as France, Austria, Germany, civil or obligation codes are over a hundred years old and still applicable. The goal of this paper aimed to be achieved, from the scientific aspect will be reflected and based on a comprehensive comparative legal analysis of

1 Lazić, M., Planojević, N. (2011). Novine u regulativi stvarnog prava Crne Gore: subjekti, objekat, državina i hipoteka. U: S. Perović (ur.). Aktuelna pitanja savremenog zakonodavstva (str. 39-55). Beograd: Savez udruženja pravnika Srbije i Republike Srpske.

2 The only exceptions are some conceptual changes in the Croatian Law on Obligations, Official Gazzette of Republic of Croatia, No. 35/05 i 41/08. 
legal regulations, both in the legislation of the Republic of Serbia and in European legislation, which is related to the subject of research. The national legislation of Serbia, Northern Macedonia, Croatia, Slovenia, and Austria were selected. Due to the limited scope of the scientific paper, it is not possible to process all the legislation of the former Yugoslav republics, as well as European countries.

\section{Temporary Service Contract in the Republic of Serbia}

In the Republic of Serbia, the temporary service contract is regulated by the Law on Obligations and the Labor Law. The Labor Law stipulates that an employer may conclude a contract with a certain person for the performance of certain tasks, for which no employment is established, the contracted work is outside the employer's activities, for example, a contract concluded under copyright regulations, a contract concerning the independent manufacturing or repair of certain goods or the independent execution of a certain physical or intellectual work. ${ }^{3}$ According to the Labor Law, the temporary service contract belongs to the group of contracts that regulate work outside of the employment sphere. In the Law on Obligations, the temporary service contract is regulated from Art. 600. until Art. 629. In legal theory, the term contract is defined in several different definitions. Contracts are one of the basic concepts in law in general, both in civil, private law, and in public law. ${ }^{5} \mathrm{~A}$ contract is the consent of will of two or more persons by which a legal effect is achieved. ${ }^{6}$ Consent of declarations of will exists when at least two persons declare their will in all respects. ${ }^{7}$ Certainly, a contract presumes the existence of certain contracting parties. So, the contract is the product of the contracting parties, because they create it with their own free will. This power of the subjects of law to create, change or terminate obligatory legal relations with their consent of will is based on the generally accepted principle of autonomy of will and freedom of contract, all according to the Law of Contract and Torts. In all national laws, contractual relations are predominantly regulated by dispositive norms, norms whose content the contracting parties can change at will and adjust to their interests and circumstances of a specific contract. ${ }^{8}$

3 Labor Law, art. 199(„Official Gazette of RS“, no. 24/2005, 61/2005, 54/2009;32/2013, 75/2014, 13/2017- Consittuional Court Decision no. 11372017)

4 Law Of Contract And Torts Published in the Official Gazette of SFRJ, No. 29/78 of 26 May 1978; Amendments in Nos.: 39/85 of 28 July 1985, 45/89 of 28 July 1989 (YCC), 57/89 of 29 September 1989 and in the Official Gazette of SRJ, No. 31/93 of 18 June 1993; Final amendments in the Official Gazette of RS, No. 18/20 of 3 March 2020

5 Antić O.(2008). Obligaciono pravo: drugo izmenjeno i dopunjeno izdanje.Beograd: Službeni glasnik, str. 195.

${ }^{6}$ Perović S. (1968). Obligaciono pravo.Beograd: Naučna knjiga, Beograd, str. 1

${ }^{7}$ Loza B.(1981). Obligaciono pravo: opšti dio: drugo dopunjeno i izmijenjeno izdanje. Sarajevo : Dom štampe- Zenica, str. 86.

${ }^{8}$ Blagojević T. B., Krulj V.(1983). Redaktori. Komentar Zakona o obligacionim odnosima: prva knjiga: drugo izdanje. Beograd: Savremena administracija, str. 103. 
It is also very important that these subjects must be able to express their free will that is suitable to create, change, or terminate obligatory relations. ${ }^{9}$ According to the Law of Torts and Contracts, a temporary service contract is such a contract under which one party - the employee (contractor - conductor) undertakes to perform a certain job, or to make or repair something or to perform some physical or intellectual work, and the other party - the client (locator) is obliged to pay him a certain fee. ${ }^{10}$ From the definition of the temporary service contract, we can conclude that the subject of the obligation on the side of the client is the payment of compensation. Therefore, the work contract is similar to those contracts in which one party pays compensation. ${ }^{11}$ The work undertaken under this contract is by its nature a material (factual) work and not legal work. The contractor is not obligated to undertake legal affairs in the name and on behalf of the client, but to make or repair something for him, to transport a certain load, to perform certain intellectual work in the field of science, to give a lecture or to make a work of art in the field of painting, sculpturing, etc. ${ }^{12}$ Since this definition is broadly set, it is necessary to make certain clarification. Specific contracts that are performed through work in the domain of physical and mental work for a fee and which, by their essential properties and their origin, represent temporary service contract, that in modern law get their place as nominated contracts. Such contracts are e.g. contract on transportation of persons and goods, authorship agreements, construction contracts, etc. The second specificity of the notion of a temporary service contract refers to the work that is agreed upon by this contract. We have already mentioned that this work is not legal, but material and factual in terms of engaging the physical and mental abilities of the contractor. According to one group of theorists, ${ }^{13}$ a manufactured or repaired item is primarily a result of the agreed-upon work. However, it can be said that its scope of this contract is broader and that it is enough to say that the contractor is obliged to perform a certain job or a task. There are cases when the contractor performs a certain job without achieving the result and goal which were the purpose of the contracted work. This happens when the obligation of the contractor (by its nature) is the obligation of the means, and not the obligation of the goal. If the contractor (according to the contract) is obliged to dig a well, regardless of whether he found water or not, he fulfilled his obligation, if he acted in such a way that there were no faults in his work. When the

${ }^{9}$ Đurović R., Dragašević M. (1980). Obligaciono pravo sa poslovima prometa. Beograd: Savremena administracija, str. 79.

10 Veljković D. (2008).Ugovori u privredi : sa sudskom praksom, primerima ugovora i tužbama za ostvarenje prava iz tih ugovora: prvo izdanje.Beograd: Poslovni biro, str 802.

11 Babić I. (2008).Ugovori građanskog prava : posebni deo obligacionog prava: drugo izmenjeno izdanje. Beograd: Pravni fakultet Univerziteta UNION u Beogradu: Službeni glasnik, str. 175.

12 Perović S., Stojanović D. (1980). Komentar Zakona o obligacionim odnosima: knjiga druga. Kragujevac: Pravni fakultet, Kragujevac i Kulturni centar, Gornji Milanovac, str. 289.

13 Loza, Konstantinović, Babić, Mijačić i drugi. 
contractor is obliged by contract to treat an animal, even if the animal dies (which means that the goal was not achieved) if the contractor acted according to the contract and according to the rules of a certain profession, he fulfilled the contracted work. Therefore, in the mentioned cases, the contractor has fulfilled the obligation from the temporary service contract and does not owe damages to the other contracting party. ${ }^{14}$ From all of the above, it can be concluded that the contractor is obliged to perform only the work that has been agreed upon, as ordered by the client, regardless of whether the goal has been achieved. A contract by which one party is obliged to manufacture a certain thing from its own material is dubiously considered as a sales contract. The contract can be considered a temporary service contract if the client has agreed upon to provide a significant part of the material needed to manufacture the contracted item. In any case, a contract is considered a temporary service contract if the contracting parties were focused on the work of the contractor. ${ }^{15}$ For the legal qualification of the contract, it is not important from whose material the contractor should manufacture the ordered item, but the production process itself is important in accordance with the wishes and instructions of the ordering party and/or under his supervision, e.g. making shoes according to the design and measurements of the customer, from the contractor's materials. ${ }^{16}$

\section{Temporary Service Contract in the Legal System of the Republic of Northern Macedonia}

The changes in the legal, political, and economic system that took place in the Republic of Northern Macedonia after its independence in 1991 also had certain consequences in the field of contractual law. ${ }^{17}$ That is why many authors believe that in the Republic of Northern Macedonia, the so-called new law of obligations is developing. The new law of obligations in Northern Macedonia is the result of great changes that have taken place in recent years, from independence until today. The adoption of the new Macedonian Constitution in 1991 laid the foundations of social and economic order: political pluralism, building civil society, equality of subjects, free-market conditions of business, free competition, and pluralism of property relations. ${ }^{18}$

14 Perović S.(1980). Obligaciono pravo. Beograd : Privredna štampa, str. 710. - 712.

15 Simonović D. (2010). Ugovor o delu. Beograd : Pravna praksa: časopis za primenu propisa, br. 2.: LIBER, str. 17.

${ }^{16}$ Mijačić M.(1990).Obligacioni ugovori : drugo dopunjeno izdanje. Beograd : Savremena administracija, str. 132.

${ }^{17}$ More on codification of Macedonian civil law in: Živkovska, R. (2003). Кодификација на граѓанското право на Република Македонија. U: R. Kovačević-Kuštrimović (ur.) Građanska kodifikacija. Sv. 2 (str. 77-93). Niš: Pravni fakultet - Centar za publikacije.

18 More about the legal reforms in Macedonia and about the amendments to the federal Law on Obligations in: Galev, G., Dabović Anastovska, J., Koevski, G., Zdraveva, N., Gavrilović, N. (2008). Razvoj obligacionog prava u Republici Makedoniji: od osamostaljivanja do 2008. godine. Pravni život, vol. 57, br. 11, str. 29-46. 
On February 20, 2001, the Republic of Macedonia adopted the Law on Obligations. ${ }^{19}$ In Chapter XIV, Article 619 the temporary service contract is defined: „Со договор за дело вршителот на работата (претприемач, изведувач на работи) се обврзува да изврши определена работа, како што е изработка или поправка на некој предмет или извриување на некоја физичка или интелектуална работа и слично, а нарачувачот се обврзува за тоа да му плати надоместок ", this definition is identical to the one laid out in the Law on Contracts and Torts from 1978. Also, all articles related to the temporary service contract are identical to the articles of the Serbian Law on Contracts and Torts, but the new Macedonian Law contains a number of novelties concerning the typology of contracts, principles, offers, etc., which will be the subject of further analysis of the Law on Contracts and Torts of the Republic of Macedonia.

In relation to certain contracts laid out in the Law on Contracts and Torts from 1978, the Law on Obligations of Macedonia provides for the same typology of certain contracts as the Law on Contracts and Torts from 1978, with this list supplemented by the following contracts: gift agreement, loan agreement, partnership agreement, agreement on assignment and distribution of property during lifetime and life care contract. In addition to the mentioned amendments, the Law on Contracts and Torts of Macedonia ${ }^{20}$ has been amended with some new solutions. For the purposes of this paper, some of them will be highlighted. Thus, for example, new principles are introduced for issues that have not been regulated so far - the principle of protection of personal rights (Article 9-a), the principle of fairness (Article 10-a), and the principle of arbitrary protection of rights (Article 17-a). The Law also introduces the principle of fairness ${ }^{21}$, according to which in certain cases persons can be held liable for damage for which they would not be liable in accordance with the general rules, or to be released from responsibility. Due to the presence of fairness in other

${ }^{19}$ Civil Obligations Act. Official Gazette of Republic of North Macedonia, no. 18/01, 4/02, 5/03, 84/08, $161 / 09$..

20 The development of the new Macedonian law of obligations, after the adoption of the Law on Obligations in 2001, ie after the first amendment, moved in the direction of creating conditions for smooth and efficient trade of goods and services, which as an obligation for Macedonia arises from the Stabilization and Association Agreement. that is, after acquiring the status of a candidate country for membership in the European Union. Since this obligation is viewed through the prism of the obligation to amend the Macedonian legislation, ie. its harmonization with EU law, there was a need for amendments to the Law on Obligations of the Republic of Macedonia, as the basic law regulating the trade of goods and services. For these reasons, in April 2007, the Ministry of Justice of the Republic of Macedonia formed a working group whose goal was to prepare amendments to the Law on Obligations. During the preparation of the amendments, the working group had in mind the directives of the European Union which regulate the issues of trade of goods and services, but also the experience of the previous application of the Law on Obligations. Listed according to: Galev, G., Dabović Anastovska, J., Koevski, G., Zdraveva, N., Gavrilović, N. (2008). Razvoj obligacionog prava u Republici Makedoniji: druga novela Zakona o obligacionim odnosima iz 2008. godine. Pravni život, vol. 57, br. 11, str. 48.

21 Article 10 reads: The principle of fairness is applied in cases specified by law, such as individual cases related to liability for damages, general conditions of the contract, termination of the contract due to changed circumstances and similar situations. 
institutes (general terms of the contract or termination of the contract due to changed circumstances), this principle has been raised to the general level, which covers its eventual introduction in other institutes as well. Fairness is a principle that has been present in the law before, but it has not been raised to a general principled level. A new article is added - 12-a (legal consequences of violation of principles). According to this article, a unique solution is provided for legal consequences in case of acting contrary to the principles provided for in the Law on Contracts and Torts, in the sense that it stipulates in which cases and what consequences arise from violating the principles. Furthermore, the ways of expressing will are clearly defined (Article 20 as amended). The provision strengthens the determination of the statement of will, it is not only required for the statement to exist but also the possibility to determine with certainty its content and the identity of the person expressing his or her will, needs to exist. Also, modern communication practices are taken into account, so the means of communication are listed as one of the possible modalities of expressing will. However, having in mind the dangers, and not only the achievements arising from the modern way of communication, but the definition is also expanded to include the clarification that the way the will is expressed should ensure that its existence, content, and identity of the provider can be concluded. However, having in mind the dangers, and not only the benefits arising from the modern way of communication, but the definition is also expanded to include the clarification that the way the will is expressed should ensure that its existence, content, and identity of the provider can be determined.

In the provisions governing the issue of negotiations, offer and acceptance of the offer, as well as the form of the contract, the Macedonian legislator tried to harmonize the Macedonian legislation in the field of contract law with the standards set in the legislation of EU member states and international sources of contract law. The amendments clearly define the rights and obligations of the parties during the negotiations in relation to confidential information obtained in the negotiation process. More specifically, two new paragraphs have been added to Article 22, which stipulate the obligation of the contracting parties to keep classified information obtained during the negotiation process a secret. The principle of conscientiousness and honesty at the pre-contractual level during the negotiations puts the participants in a specific relationship of trust and orders them to take care not only of their own interest but also of the interest of the other party. Regardless of whether the contract is concluded or not, the party who obtained classified information cannot use them or make them available to third parties. The law or other legal acts act determine which information will be considered confidential. In case of violation of this principle, the injured party has the right to damages according to the general rules for liability for damage. The Law on Contracts and Torts regulates in principle the issue of the use of means of communication, including electronic ones, as a way of expressing one's will. A new article was introduced - an offer made electronically (Article 24-a). 
This article defines that an offer made by means of communication is considered an offer between absent persons. In cases where an answer can be given immediately by means of electronic communication, the offer shall be considered like it was made in person unless otherwise provided by law. Changes were also made in the direction of clarifying and rounding off the provisions related to the validity period of the offer and the form of the offer. ${ }^{22}$ In this way, the institute of the general offer is harmonized with the principles of European contract law (PECL).

A new article (30-a) was introduced, which stipulates that a written offer is given on a memorandum, and signed by an unauthorized person, will be considered binding cumulative with the fulfillment of several conditions: that the offer was given on form used by the bidder in its regular business (memorandum) and that it was written in the usual way, that it refers to the activity in which the bidder is regularly engaged and that it falls under its regular scope, and that the other side did not know or could not have known that the bid was signed by an unauthorized person.

One of the major innovations is the introduction of definitions, ie the regulation of the institutes of "legal capacity" and "business capacity". In essence, the given definitions are those that have been used for many years in Macedonian legal science and jurisprudence. They fully comply with modern civil codes in Europe. ${ }^{23}$ In the part related to the form of the contract, a new Article 59-a has been added, which stipulates that the contract concluded orally should be confirmed in writing. The article also defines the manner and procedure of written confirmation of contracts, which was introduced to strengthen legal certainty and facilitate the proof of orally concluded contracts.

Amendments to the Law on Contracts and Torts also contain provisions related to damages. Thus, for example, in Chapter II, Section 2 - Causing Damage, changes were made that were imposed as a necessity, after the shortcomings of the previous application of the Law on Contracts and Torts were made obvious. The definition of the basis of liability is specified with the amendment of Article 14, paragraph $1 .^{24}$ A more precise and clearer distinction has been made between liability based on guilt (subjective liability) and liability from things and actions that result in increased danger (objective liability). ${ }^{25}$

\footnotetext{
22 More in: Galev, G., Dabović Anastovska, J., Koevski, G., Zdraveva, N., Gavrilović, N. (2008). Razvoj obligacionog prava u Republici Makedoniji: druga novela Zakona o obligacionim odnosima iz 2008. godine. Pravni život, vol. 57, br. 11, str. 53-55.

23 More in: Galev, G., Dabović Anastovska, J., Koevski, G., Zdraveva, N., Gavrilović, N. (2008). Razvoj obligacionog prava u Republici Makedoniji: druga novela Zakona o obligacionim odnosima iz 2008. godine. Pravni život, vol. 57, br. 11, str. 53-55.

${ }^{24}$ Article 141, paragraph 1 of the Law on Obligations of the Republic of Macedonia reads: Whoever causes damage to another through his own fault, is obliged to compensate it.

25 Articles 145 and 159 of the Law on Obligations of the Republic of Macedonia.
} 
There are amendments to certain articles that also apply to certain contracts contract of sale (Chapter VII), contract of construction (Chapter XV), contract of commercial representation (Chapter XXIII), contract of assignment of property for life (Chapter XXXI).

\section{Temporary Service Contract in the Legal System of the Republic of Croatia}

The Croatian Law on Contracts and Torts (hereinafter: LCTHR) has taken over the formal and legal provisions of the Law on Contracts and Torts (hereinafter: LCT) from 1978, with certain amendments. In relation to individual contracts provided by the Law on Contracts and Torts of 1978, the LCTHR provides for the same typology of contracts as the LCT from 1978. As for the segment on individual contracts, the Croatian Law added only one contract - a partnership contract - which was not provided for in the 1978 Law. Regarding the temporary service contract, the LCTHR took over the provisions of the 1978 LCT with minor corrections that generally apply to all contracts. Therefore, in the following text, the emphasis will be on these corrections. On June 26, 1991, the Republic of Croatia passed the Law on Taking Over the Law on Contracts and torts. ${ }^{26}$ The temporary service contract in the LCTHR is regulated by Articles 590-619. The term temporary service contract in the LCTHR is defined in Article 590, which reads: "Temporary service contract is such a contract, where the contractor undertakes to perform a certain job, such as making or repairing something, performing some kind of physical or mental work, etc., and the client undertakes to pay him a fee for the performed work." Although the legislator, with his legal norms, tries to foresee as many legal solutions as possible in advance, he still cannot cover and foresee all life situations that arise in reality. Even when there is an all-encompassing legal norm in a particular case, applying that and such norms can create injustice. Therefore, there are basic legal principles that fill legal gaps and can correct unfair legislative solutions. ${ }^{27}$ In legal matters, out of all the principles, the ruling principle of conscientiousness and honesty, to which Article 4 of the LCTHR refers, holds a special place. ${ }^{28}$ For certain contracts in the LCTHR, the law provides for certain deviations from the general rules on

\footnotetext{
${ }^{26}$ Official Gazette, no. 53/91, 73/91, 3/94, 7/96, 112/99, 88/01 and 35/05. The new Law on Obligations was published in the Official Gazette no. 35/05, 17 March 2005, and entered into force on 1 January 2006, with the provisions of Art. 26, para. 1-3 and Art. 29, para. 2-6 and st. 8 shall enter into force after the expiration of two years from the date of entry into force of this Law. In the new law, certain, and in some aspects significant changes in the rules governing liability for material defects have been introduced into the Croatian legal order. Therefore, the author will analyze the mentioned changes related to the work contract.

27 Pavlović, M. (2014). Dužno ponašanje sudionika u ispunjavanju obveza. Zbornik radova Pravnog fakulteta u Splitu, vol. 51, br. 3, str. 578.

28 This principle is also explicitly mentioned in the provisions of Articles 29, 174, 296, 297, 344, 371, $811,817,838,839$ and 1117 of the LCTHR.
} 
termination of obligations, such as in the case of temporary service contracts, as described in Article 619. This article prescribes the termination of the contract by the will of the client in such a way that until the ordered work is completed, the client can terminate the contract whenever he wants, but in that case, he is obliged to pay the contractor the agreed compensation, reduced by the hight of costs he did not have, which would usually be incurred had the contract not been terminated, and for the hight of earnings that the contractor earned from other sources or for the earnings that he deliberately failed to realize. The LCTHR stipulates in a number of provisions that a participant in an obligatory relationship is obliged to act with due professional care, according to the rules of the profession and customs, if he is contracted for work in his professional activity. However, neither the LCTHR nor the special customs further explain what are the rules of the profession or the rules of the job. Pavlović believes that the rules of the profession represent a set of scientific and professional experiences, which have been confirmed in practice and thus become obligatory for the common good of all those who are engaged in a certain activity. ${ }^{29}$ For the most part, these rules are not contained in the legislature, so for these reasons they are often unwritten rules according to which a certain activity is performed, that is, they are experiences that experts have who perform a certain professional job in a certain branch. Therefore, the application of the rules of the profession is possible only if experts are professionally engaged in a certain profession. The basic criterion for the valid rules of the profession is their regular application in reality because the prescribed professional norms (standards) are often lagging behind the continuous development of new technologies and achievements. Therefore, only the objective criterion of actions of experts (professionals) from a certain field of activity at a certain moment should be taken into account. Following that line of thought, the provision of Article 612 of the LCTHR stipulates that the client is obliged to accept the work performed according to the provisions of the contract and the rules of the profession. General rules on the impact of changed circumstances on the contract can be found in the chapter dedicated to the performance of bilaterally binding onerous contracts, from Article 357 to Article 375. In addition to the rules on modification or termination of the contract due to changed circumstances, there are also rules on liability for material and legal deficiencies, rules on objections of non-performance and objections of uncertain performance of contracts, rules on unilateral termination of contracts due to non-performance, rules on the impossibility of performance, and excessive damage. The application of these institutes is only possible in the case of contracts in which both parties undertake the obligation to perform a certain act, and their basic purpose is to remove the existing or prevent the threatening disturbance of the contractual equilibrium. This determines the scope of application of the rules on

${ }^{29}$ Pavlović, M. (2014). Dužno ponašanje sudionika u ispunjavanju obveza. Zbornik radova Pravnog fakulteta u Splitu, vol. 51, br. 3, str. 575-600. 
the rebus sic stantibus clause in Croatian law, but also raises some more questions. ${ }^{30}$ At the level of the general institute, LCTHR regulates material liability as liability for deficiencies, which means that in each contract the debtor is liable if he fails to fulfill the agreed performance as stipulated in the contract, or in the absence of special contractual provisions - as required by law. This means that it is not only a matter of responsibility for the defects of the material thing that is the subject of the contract, but it can be any factual defect that is manifested in the final performance and actions equal to performance or actions of omission. ${ }^{31}$ However, since in practice this liability most often appears in connection with the defected goods in sales contracts, and that the institute historically arose as a form of seller's liability for defects in the sold goods, LCTHR stipulates in Article 357 paragraph 3 that the provisions on the seller's liability for material and legal defects, provisions of Art. 400-422 LCTHR is equal and applicable to liability for material defects. At the same time, these provisions declare the rules on the seller's liability for material defects as general rules, more precisely, rules that are valid as a lex generalis for all cost contracts, which means that they apply only if something else is not prescribed for certain contracts. ${ }^{32}$ Another novelty in determining the cases in which the goods are considered to have a material defect are the rules of Article 401, paragraph 1, items 6 and 7 of the LCTHR. According to these provisions, the item has a defect if it is incorrectly installed, provided that the installation service is included in the fulfillment of the sales contract, as well as if the incorrect installation is a consequence of errors in the installation instructions. The rules of Article 2, paragraph 5 of Directive 1999/44 is hereby accepted, subject to certain, minor changes. The goods in question (primarily consumer goods) are delivered in parts and require subsequent assembly. In order for the assembly service to be considered a separate contract, for example, a temporary service contract, it has to be explicitly prescribed that defects resulting from the improper installation are considered material defects in terms of liability. ${ }^{33}$

\footnotetext{
30 More in: Petrić, S. (2007). Izmjena ili raskid ugovora zbog promijenjenih okolnosti prema novom Zakonu o obveznim odnosima. Zbornik Pravog fakulteta Sveučilišta u Rijeci, vol. 28, br. 1, str. 23.

${ }^{31}$ Precisely because it is about responsibility for fulfillment, and not exclusively about responsibility for the shortcomings of goods, ie. As the liability is not limited to contractual obligations in which the subject of the act is the delivery of goods, the literature states that it would be better to use the term "factual defect" instead of the term "material defect", since the semantic meaning of the term material defect indicates that it is exclusively about shortcomings in the goods themselves. Listed by: Gorenc, V., Belanić, L., Momčinović, H., Perkušić, A., Pešutić, A., Slakoper, Z., Vukelić, M., Vukmir, B. (2005). Komentar Zakona o obveznim odnosima. Zagreb: RRiF, str. 531.

32 Posebne odredbe o odgovornosti prenositelja za materijalne nedostatke ZOO predviđa kod ugovora o delu (članovi 604-611).

33 Petrić, S. (2006). Odgovornost za materijalne nedostatke stvari prema novom Zakonu o obveznim odnosima. Zbornik Pravnog fakulteta Sveučilišsta u Rijeci, vol. 27, br. 1, str. 108.
} 


\section{Temporary Service Contract in the Legal System of the Republic of Slovenia}

The new Slovenian law in the field of obligations is based on the 1978 Law on Contracts and Torts. The Law on Contracts and Torts, as a federal law, was valid on the territory of the Republic of Slovenia until the declaration of its independence on June 25, 1991. After that, on the basis of Article 4 of the Constitutional Law on the Implementation of the Basic Constitutional Charter on Independence and Autonomy, that law was valid in the Republic of Slovenia, now as national law. After several years of preparations, a new Slovenian Code of Obligations (Obligation Code; hereinafter: OZ) was adopted in October 2001, which has been in force since January

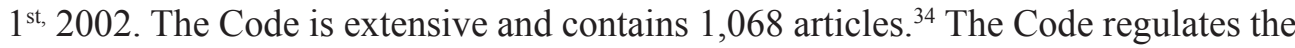
basic principles and general rules for all obligations, and almost entirely took over the legal solutions, systematics, and labeling from the Law on Contracts and Torts. ${ }^{35}$ In relation to certain contracts provided by the Law on Contracts and Torts from $1978, \mathrm{OZ}^{36}$ provides for the same typology of individual contracts, with the addition of the following contracts to its code: gift agreement, contract on distribution of property during the lifetime, lifetime support agreement, loan agreement, partnership agreement, letter of credit. ${ }^{37}$ It is important to note that the banking agreements have not been adopted from the Law on Contracts and Torts. ${ }^{38}$ Specifically, in relation to the temporary service contract, the very concept of the temporary service contract in the OZ is defined in Article 619 and reads: „S podjemno pogodbo se podjemnik zavezuje opraviti določen posel, kot je izdelava ali popravilo kakšne stvari, kakšno telesno ali umsko delo ipd., naročnik pa zavezuje, da mu bo za to plačal. ${ }^{“{ }^{39}}$ The provisions governing the temporary service contract, in other words the obligations of the contractor and the client are identical to those in the Law on Contracts and Torts, and are covered by Articles 619-648. Although the provisions of the OZ, which regulate the temporary service contract, are identical to the provisions of the Law on Contracts and Torts, it also contains some amendments and novelties, and some of them will be discussed in more detail below. Thus, for example, the Slovenian

34 The last changes were made in 2007, today it contains 1,062 articles.

35 Mihailović, N. (2002). Novi Obligacijski zakonik Republike Slovenije. Pravo-teorija i praksa, vol. 19 , br. 5-6, str. 71.

36 Official Gazette of RS, no. 83/01, 32/04, 40/07. Available at: https://www.uradni-list.si/1/ content?id=82804

37 The provisions of the sales contract (Articles 435-527) of the Code of Obligations that were taken over from the Law on Obligations (Articles 454-527) were supplemented only by the provisions on letter of credit (Article 527 of the Code of Obligations).

38 Perović, S. (2008). Kodifikacije ugovornog prava u savremenim uslovima. Pravni život. vol. 57, br. 11 , str. 12.

39 The temporary service contract is a contract that obliges the contractor to perform a certain job, such as making or repairing something or performing some physical or intellectual work, etc., and the client is obliged to pay him compensation (Article 600 of the Law on Contracts and Torts of the Republic of Serbia). 
legislator took over the relevant provisions from the Law on Contracts and Torts on the statute of limitations for claims, with certain amendments. According to Article 345 of the $\mathrm{OZ}$, the general statute of limitations is five years, while according to the Law on Contracts and Torts, the same statute of limitations is ten years (Article 371), based on which it is concluded that the Slovenian legislator did not accept the extension of the general statute of limitations.

Article 371 of the $\mathrm{OZ}^{40}$ stipulates that the principle of monetary nominalism applies when performing monetary obligations, with Article 371 of the $\mid \mathrm{OZ}$ stating: unless the creditor and the debtor, in accordance with the law, agree otherwise. The new Article 372 of the $\mathrm{OZ}$ provides for the valorization of monetary claims, which is provided by contracting an index or currency clause, or by linking to some other price change if such a contract is not contrary to law.

The rules of liability for damage caused by a defective product are incorporated in the Consumer Protection Act applied in Slovenia (Zakon o varstvu potrošnikov ${ }^{41}$ ). However, it is important to note that the $\mathrm{OZ}$ of the Republic of Slovenia also regulates in one article (Article 155) the matter of liability for damage caused by a defective product. ${ }^{42}$ This brings the relationship between $\mathrm{OZ}$ and the Consumer Protection Act in question. The provisions of the Law on Consumer Protection on liability for damage caused by defective product support and enable a more precise interpretation of the provision of Article 155, which is identical to Article 179 of the Law on Contracts and Torts of the Republic of Serbia. ${ }^{43}$

\section{Temporary Service Contract in the Austrian Civil Code}

The fact is that although the Austrian Civil Code has been amended many times in the last hundred years - Austria is not planning to start drafting a new civil code. Although there is talk in Austrian legal circles of a major revision of the Austrian Civil Code, the opinions of eminent university professors and judges of the highest courts remain uniform. More precisely, they are of the opinion that Austria should not start drafting a new civil code. Instead, the Austrian Civil Code (German: Allgemeines Bürgerliches Gesetzbuch - ABGB) will be even more adapted to the needs of modern society. ${ }^{44}$ In that way, formally, the tradition will be preserved, and the Austrians will

\footnotetext{
40 Art. 394 of the Law on Contracts and Torts is identical

41 Consumer Protection Act / ZVPot /, Offical Gazette RS, no. 20/98 (25/98 - corr.), 23/99 (25/98 corr.), 110/02 (25/1998 - corr.), 51/04 (25/98 - corr.). Article 11a of the Law on Consumer Protection stipulates that the provisions on liability for damage caused by a defective product also apply to persons who are not consumers according to the said law.

42 This article is identical in content to Article 179 of the Law on Obligations of the Republic of Serbia.

${ }^{43}$ More about the significant differences between $\mathrm{OZ}$ and $\mathrm{ZOO}$ in the field of causing and compensation of damages and interest in: Mihailović, N. (2002). Novi Obligacijski zakonik Republike Slovenije. Pravo - teorija i praksa, vol. 19, br. 5-6, str. 70-75.

44 This link contains current Austrian legislation: http://www.ris.bka.gv.at/GeltendeFassung. wxe? Abfrage $=$ Bundesnormen\& Gesetzesnummer $=10001622$
} 
get modern legal regulations at the same time. ${ }^{45}$ The temporary service contract in the Austrian Civil Code is defined by the provisions of paragraph 1165, which reads: the contractor is obliged to perform the contracted work personally or to have it performed under his personal responsibility. Based on the content of the mentioned paragraph, it can be concluded that it does not contain the definition of a temporary service contract, but the obligation of the contractor to personally perform the work or through a sub-contractor while remaining personally responsible. Also, the next paragraph is not dedicated to the definition of temporary service contracts, but the differentiation of temporary service contracts and sales contracts. Paragraph 1166 stipulates: if the contractor has to provide the materials needed for the job in question, it is a sales contract, but if the client supplies the material, it is considered to be a temporary service contract. Based on the above, it is concluded that although the temporary service contract is explicitly nominated in the Austrian Civil Code, the Code fails to define it. However, if we analyze the paragraph $1151^{46}$, which reads: if someone commits to perform work for another for a certain period of time, a service contract is created, and a temporary service contract if the contractor takes over the production of a specific item for a fee. It can be said that the mentioned paragraph, although imprecise because it does not contain information on the contractor and the client, is still closer to the definition of the temporary service contract than paragraph 1165. If the work contains significant defects that make the work unusable or the work is made contrary to the requirements of the client, the client may terminate the contract. However, if the defects are not significant or do not conflict significantly with the contracted conditions, the client may request a repair if this would not involve high costs or a significant reduction in value. In order to facilitate repairs, the client must leave a reasonable deadline to the contractor, with a statement that after the expiration of the deadline, the repairs will not be accepted. ${ }^{47}$ If the product of the contracted work perishes ${ }^{48}$ in some way before the due performance, the contractor cannot demand compensation. Loss of material affects the party who provided it, but if the production fails due to poor quality of materials provided by the client or due to clearly incorrect instructions given by the client, the contractor is liable for damage if he did not warn the client of said shortcomings ( $\$ 1168 \mathrm{a}$ ). As a rule, compensation for the contracted work is paid when the work is completed, and if the production process consists of certain stages, the contractor is authorized to request compensation in advance in proportion to the expenses incurred. ${ }^{49}$ The temporary

45 Nikolić, D. (2011). Dva veka Austrijskog građanskog zakonika (1811-2011). Zbornik Matice srpske za društvene nauke, vol. 62 , br. 135, str. 318 .

46 Service contract is an employment contract.

47 Paragraph 1167 of the Austrian Civil Code

48 The cases are not specified

49 Paragraph 1170 of the Austrian Civil Code 
service contract may be terminated by the death of the contractor, and his heirs may claim compensation for the prepared and usable materials, as well as the part of the compensation proportional to the work done. On the other hand, if the client dies, the heirs remain bound by the contract ( $§ 1171)$. The above-mentioned provisions of the temporary service contract are supplemented by the following paragraph. In that sense, paragraph 934 of the Austrian Civil Code stipulates that in the event that one party has not received even half of the regular value of what it has given to the other party in a bilaterally onerous transaction, that party has the right to demand termination and restitution. The other contracting party has the right to "keep the contract in force" if it agrees to compensate the difference up to the regular value of the performance of the injured party, and the disproportion of the value is determined according to the moment of contract conclusion. The moment of concluding the contract is considered as the moment of accepting the power of attorney unless there is an explicit refusal. According to the Austrian Civil Code, ie paragraph 871, which reads: if one party is misled by the other party with false allegations, and the misconception concerns the reason the contract was concluded, or some of its essential features of the contract, to which the intention was specifically directed and stated - then there is no obligation for the misled party. Also, the debtor's liability for damage due to breach of contract is not limited to foreseeable damage..$^{50}$ In paragraph 918 (2), the Austrian Civil Code is clear with regard to divisible obligations because it provides that if an obligation is divisible to both parties, separate parts of the performance may be waived due to the delay of one or all parts of the performance. The Austrian Civil Code does not contain general provisions on the autonomy of the will, but this principle is derived in a limited sense from the rule that contracts can be concluded on everything that can be traded. It is also emphasized that the subject of a valid contract cannot be what cannot be done, what is completely impossible or what is inadmissible ( $\S$ 878 ) and that a contract that is contrary to (or violating) a legal prohibition or good custom is null and void ( $\S 879$ ). The method of concluding a contract is mandatory in the Austrian Civil Code only if the time of conclusion and the essential parts of the contract are specified ( $(936)$. The codifications of civil law in the $19^{\text {th }}$ and $20^{\text {th }}$ centuries fully accept the principle of consensualism (solus consensus obligat). The principle of consensualism has been adopted by the Austrian Civil Code in a general way - that a contract can be made orally or in writing in court or out of court, with or without witnesses. Such a difference in form does not make any difference in respect to the obligation and its performance, except as provided by law ( $(883)$. The French legislator, for example, did not define this principle at all in a general way because they considered it to be implied and a well-known fact.

50 Jankovec, I. (1993). Ugovorna odgovornost. Beograd: Poslovna politika, str. 347. 


\section{Conclusion}

The temporary service contra survived various social structures during its evolution but still retained its basic characteristics. A comparative analysis of the temporary service contract leads to the conclusion that this contract is regulated in the same manner in both countries of the European Union, as well as in the countries of the region, and as in the Law on Contracts and Torts of the Republic of Serbia. In reality, this contract is very common, and given the development of society and the speed of commercial activity, it is expected that the temporary service contract will be increasingly used in the future. Based on the conducted comparative research, it can be concluded that the temporary service contract is regulated in the civil codes of European countries and that in its legal essence it does not differ from the legal concept of the temporary service contract as regulated in the Law on Contracts and Torts of the Republic of Serbia. It is regulated by Articles 1165-1171 in the Austrian Civil Code. In the codes of the former Yugoslav republics, Slovenia, Northern Macedonia, Croatia, the text of the Law on Contracts and Torts from 1978 was initially taken over, and then new laws were adopted based on the said Law on Contracts and Torts with little to no corrections. These legal systems recognize the same principles and functions of the temporary service contract as the Serbian legal system.

\section{Bibliography}

1. Antić O.(2008). Obligaciono pravo: drugo izmenjeno i dopunjeno izdanje. Beograd: Službeni glasnik

2. Babić I. (2008).Ugovori građanskog prava : posebni deo obligacionog prava: drugo izmenjeno izdanje. Beograd: Pravni fakultet Univerziteta UNION u Beogradu: Službeni glasnik

3. Blagojević T. B., Krulj V.(1983). Redaktori. Komentar Zakona o obligacionim odnosima: prva knjiga: drugo izdanje. Beograd: Savremena administracija

4. Đurović R., Dragašević M. (1980). Obligaciono pravo sa poslovima prometa. Beograd: Savremena administracija

5. Galev, G., Dabović Anastovska, J., Koevski, G., Zdraveva, N., Gavrilović, N. (2008). Razvoj obligacionog prava u Republici Makedoniji: od osamostaljivanja do 2008. godine. Pravni život, vol. 57, br. 11

6. Gorenc, V., Belanić, L., Momčinović, H., Perkušić, A., Pešutić, A., Slakoper, Z., Vukelić, M., Vukmir, B. (2005). Komentar Zakona o obveznim odnosima. Zagreb: RRiF

7. Jankovec, I. (1993). Ugovorna odgovornost. Beograd: Poslovna politika

8. Kovačević-Kuštrimović, R., Lazić, M. (2008). Građanski zakonik Srbije i pravo Evropske unije.

9. Kovačević- Kuštrimović (ur.) Aktuelna pitanja građanske kodifikacije (str. 1734). Niš: Pravni fakultet - Centar za publikacije

10. Kovačević-Kuštrimović (ur.) Građanska kodifikacija. Sv. 2 (str. 77-93). Niš: 
Pravni fakultet - Centar za publikacije

11. Lazić, M., Planojević, N. (2011). Novine u regulativi stvarnog prava Crne Gore: subjekti, objekat, državina i hipoteka

12. Loza B.(1981). Obligaciono pravo: opšti dio: drugo dopunjeno i izmijenjeno izdanje. Sarajevo : Dom štampe- Zenica

13. Mijačić M.(1990).Obligacioni ugovori : drugo dopunjeno izdanje. Beograd : Savremena administracija

14. Mihailović, N. (2002). Novi Obligacijski zakonik Republike Slovenije. Pravoteorija i praksa, vol. 19, br. 5-6

15. Nikolić, D. (2011). Dva veka Austrijskog građanskog zakonika (1811-2011). Zbornik Matice srpske za društvene nauke, vol. 62, br. 135

16. Perović S. (1968). Obligaciono pravo.Beograd: Naučna knjiga, Beograd

17. Perović S., Stojanović D. (1980). Komentar Zakona o obligacionim odnosima: knjiga druga. Kragujevac: Pravni fakultet, Kragujevac i Kulturni centar, Gornji Milanovac

18. Perović S.(1980). Obligaciono pravo. Beograd : Privredna štampa

19. Perović (ur.). Aktuelna pitanja savremenog zakonodavstva (str. 39-55). Beograd: Savez udruženja pravnika Srbije i Republike Srpske

20. Pavlović, M. (2014). Dužno ponašanje sudionika u ispunjavanju obveza. Zbornik radova Pravnog fakulteta u Splitu, vol. 51, br. 3

21. Petrić, S. (2006). Odgovornost za materijalne nedostatke stvari prema novom Zakonu o obveznim odnosima. Zbornik Pravnog fakulteta Sveučilišta u Rijeci, vol. 27 , br. 1

22. Petrić, S. (2007). Izmjena ili raskid ugovora zbog promijenjenih okolnosti prema novom Zakonu o obveznim odnosima. Zbornik Pravog fakulteta Sveučilišta u Rijeci, vol. 28, br. 1

23. Simonović D. (2010). Ugovor o delu. Beograd : Pravna praksa: časopis za primenu propisa, br. 2.: LIBER

24. Veljković D. (2008).Ugovori u privredi : sa sudskom praksom, primerima ugovora i tužbama za ostvarenje prava iz tih ugovora: prvo izdanje.Beograd: Poslovni biro

25. Živkovska, R. (2003). Кодификација на граѓанското право на Република Македонија

26. Law on Contracts and Torts („Official Gazette of SFRJ“, no. 29/78, 39/85, 45/89- decision of USJ and 57/89, „Official Gazette of SRJ“, no. 31/93 i „Official Gazette of SCG“, no. 1/2003-Constitutional Declaration)

27. Labor Law („Official Gazette of RS“, no. 24/2005, 61/2005, 54/2009;32/2013, 75/2014, 13/2017- decision US i 11372017)

28. Civil Obligations Act, Official Gazette of the Republic of Croatia, no. 35/05 i $41 / 08$.

29. Civil Obligations Act. Official Gazette of the Republic of North Macedonia, no. 
18/01, 4/02, 5/03, 84/08, 161/09.

30. Official Gazette of the Republic of Croatia, no. 53/91, 73/91, 3/94, 7/96, 112/99, $88 / 01$ i $35 / 05$

31. Consumer Protection Act /ZVPot/, Official Gazette of the Republic of Slovenia, no. 20/98 (25/98 - popr.), 23/99 (25/98 - popr.), 110/02 (25/1998 - popr.), 51/04 (25/98 - popr.).

32. Official Gazette of the Republic of Slovenia, no. 83/01, 32/04, 40/07. Available at: https://www.uradni-list.si/1/content?id=82804

33. The current legislature of Austria available at the following link: http://www.ris. bka.gv.at/GeltendeFassung.wxe?Abfrage=Bundesnormen\& Gesetzesnummer $=10001622$ 